\title{
Oxygenation of Neutral Ferrous Sulfate Solution by Gas Bubbling
}

\author{
Binzo HiguCHI*, Yoshizumi KaWAGUCHI**, \\ Zenjiro ASAKI** and Yoshio KONDO**
}

\begin{abstract}
The oxidation of $\mathrm{FeSO}_{4}$ solution by $\mathrm{O}_{2}$ gas was studied at $\mathrm{pH}$ between 6.0 and 7.7 . The oxidation was presumed to be composed of the sequential steps of dissolution of $\underline{\mathrm{O}}_{2}$ gas and reaction between $\mathrm{Fe}^{2+}$ ion and $\mathrm{O}_{2}$, and the rate determining steps were pursued. The rate of oxidation increased with $\mathrm{pH}$. In the region of $\mathrm{pH}$ above 6.7 (at $25^{\circ} \mathrm{C}$ and $\mathrm{Re} 4000$ ), the overall rate was controlled by the transferring rate of ${\underline{\mathrm{O}_{2}}}_{2}$ in the liquid boundary film adjacent to the gas bubbles. The rate of reaction between $\mathrm{Fe}^{2+}$ ion and $\underline{\mathrm{O}_{2}}$ was revealed to be proportional to the $4 / 3$ th power of $\mathrm{C}_{\mathrm{OH}^{-}}$. At the temperature below $15^{\circ} \mathrm{C}$, (at $\mathrm{pH} 6.8$ and $\mathrm{Re} 1000$ ), the overall rate was affected by both rates of mass transfer of $\underline{\mathrm{O}}_{2}$ and chemical reaction. From the calculated rate constant of the reaction between $\mathrm{Fe}^{2-}$ ion and $\underline{\mathrm{O}_{2}}$, the activation energy of $21 \mathrm{kcal} / \mathrm{mol}$ was obtained. The overall rate of oxidation increased with flow rate of gas stream (at $25^{\circ} \mathrm{C}$ and $\mathrm{pH} 6.8$ ). At lower Reynolds number, the oxidation was of mass transfer control. When Reynolds number was higher, it was of mixed control of mass transfer $\underline{\mathrm{O}_{2}}$ and of chemical reaction.
\end{abstract}

\section{Introduction}

The oxidation of ferrous sulfate by $\mathrm{O}_{2}$ gas in the aqueous solution is composed of the sequential steps of the dissolution of $\mathrm{O}_{2}$ gas at the surface of rising gas bubbles and the reaction between $\mathrm{Fe}^{2+}$ ion and dissolved oxygen. ${ }^{1)}$

They are represented as

$$
\mathrm{O}_{2}=\underline{\mathrm{O}_{2}}
$$

and

$$
\begin{aligned}
& 4 \mathrm{FeSO}_{4} \div \mathrm{O}_{2}+2 \mathrm{H}_{2} \mathrm{SO}_{4} \\
& \quad=2 \mathrm{Fe}_{2}\left(\mathrm{SO}_{4}\right)_{3}+2 \mathrm{H}_{2} \mathrm{O} \quad \mathrm{pH}<\mathrm{ca} .4
\end{aligned}
$$

or

$$
\begin{aligned}
& 4 \mathrm{FeSO}_{4}+\underline{\mathrm{O}_{2}}+10 \mathrm{H}_{2} \mathrm{O} \\
& \quad=4 \mathrm{Fe}(\mathrm{OH})_{3}+4 \mathrm{H}_{2} \mathrm{SO}_{4} \mathrm{pH}>\mathrm{ca} .4
\end{aligned}
$$

respectively. The notation $\underline{\mathrm{O}_{2}}$ represents the dissolved oxygen. It should be noted that the rate of eq. (1) is affected by the hydrodynamic conditions of gas bubbling, whereas the rates of eq. (2) and (3) are not laffected because of their homogeneous character.

It was found in the previous study on the air oxidation of ferrous sulfate in an alkaline solution ${ }^{13}$ that no catalytic effect of $\mathrm{Cu}^{2+}$ ion was observed and the overall rate was not

* Department of Metallurgy, Tsuyama Technical College (Tsuyama, Okayama)

** Department of Metallurgy, Kyoto University (Yoshidahonmachi, Sakyo-ku, Kyoto) virtually affected by the temperature, but that the rate increased with the rise of flow rate of air and a zero order rate equation was found to hold. It was concluded that the rate determining step is the oxygen dissolution shown in eq. (1).

It is known $^{2 \sim 4)}$ in the region of $\mathrm{pH}$ between 4 and 7.5 , on the other hand, that the overall rate of air oxidation of $\mathrm{Fe}^{2+}$ ion is proportional to the concentration of $\mathrm{Fe}^{2+}$ ion and to the second power of the concentration of $\mathrm{OH}^{-}$ion in the solution. It is expected in this region of $\mathrm{pH}$ that both eq. (1) and (3) may affect the overall rate. From the industrial point of view, the air oxidation of $\mathrm{Fe}^{2+}$ ion in this $\mathrm{pH}$ region is important to our basic knowledge about the iron removal from the pregnant solution from leaching processes.

Stumm and Lee ${ }^{27}$ studied the kinetics of the reaction between $\mathrm{Fe}^{2+}$ ion and $\mathrm{O}_{2}$ gas at $\mathrm{pH}$ between 6.0 and 7.5. The partial pressure of $\mathrm{O}_{2}$ gas and $\mathrm{pH}$ of the solution were maintained constant during each experimental run by bubbling a mixture of $\mathrm{CO}_{2}$ and air through the test solution. Various $\mathrm{pH}$ values were obtained by using air $-\mathrm{CO}_{2}$ mixture of different compositions. From the presumption that $C_{\mathrm{O}_{2}}$ is proportional to $p_{\mathrm{O}_{2}}$ in the gas mixture, the follow- 
ing rate equation was proposed.

$$
-\frac{\mathrm{d} C_{\mathrm{Fe}^{2+}}}{\mathrm{d} \theta}=k C_{\mathrm{Fe}^{2+}} p_{\mathrm{O}_{2}} C_{\mathrm{OH}^{-}}^{2}
$$

The activation energy of $23 \mathrm{kcal}$ was obtained at a constant $\mathrm{pH}$. Furthermore, the catalytic effect of $\mathrm{Cu}^{2-}$ ion was found to be considerable for the concentration of $3 \times 10^{-7} \mathrm{M}$, but it increased only slowly with the concentration. Schenk et al. ${ }^{3)}$ and Tamura et al. ${ }^{4)}$ also studied the catalytic effects of dissolved silica and ferric hydroxide on the rate of air oxidation of $\mathrm{Fe}^{2+}$ ion in the neutral solution, respectively.

It was intended in the present work to study the kinetics of oxidation of ferrous sulfate by oxygen in the aqueous solution of $\mathrm{pH}$ between 6.0 and 7.7. Not only the reaction (3) but also the reaction (1) were taken into account, and the rate determining steps of the overall reaction were pursued.

\section{Experimental}

The experimental arrangement in the present work is schematically illustrated in Fig. 1. The $\mathrm{pH}$ of the solution was maintained constant during the oxidation by bubbling gas mixture containing $\mathrm{CO}_{2}$ of a constant partial pressure. Oxygen, nitrogen and $\mathrm{CO}_{2}$ gases were sent from the gas cylinders, respectively. The flow

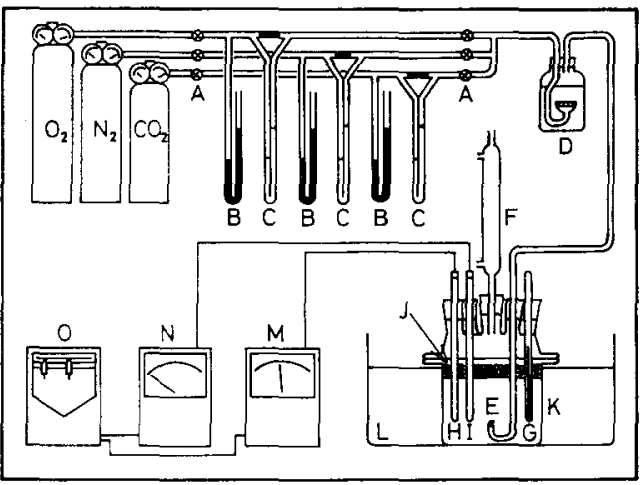

Fig. 1 Experimental arrangement (A) Valve, (B) Manometer, (C) Capillary flowmeter, (D) Humidifier, (E) Nozzle, (F) Reflux condenser, (G) Thermometer, (H) Combined glass electrode, (I) Platinum electrode for measuring $C_{\mathrm{O}_{2}}$, ( $\mathrm{J}$ ) Styrofoam floats, (K) Reaction vessel, (L) Thermostat,

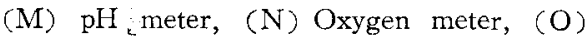
Recorder rate of these gases was separately measured with the capillary flowmeters. After passing through a humidifier, the gas mixture was blown from a glass nozzle into the solution.

The reaction vessel was a $1000 \mathrm{~cm}^{3}-$ cylindrical glass flask provided with a glass lid with five holes and was placed in a thermostat. The inner dimension of the flask was $114 \mathrm{~mm}$ in inner diameter and $125 \mathrm{~mm}$ in height. Through the holes of the glass lid, a glass nozzle, a thermometer, a combined glass electrode, a platinum electrode for measuring $C_{\underline{\mathrm{O}_{2}}}$ and a reflux condenser were installed, respectively.

An upward vertical glass nozzle of $0.5 \mathrm{~mm}$ in inner diameter was used. Its dimension is shown in Fig. 2. The measurements of $\mathrm{pH}$

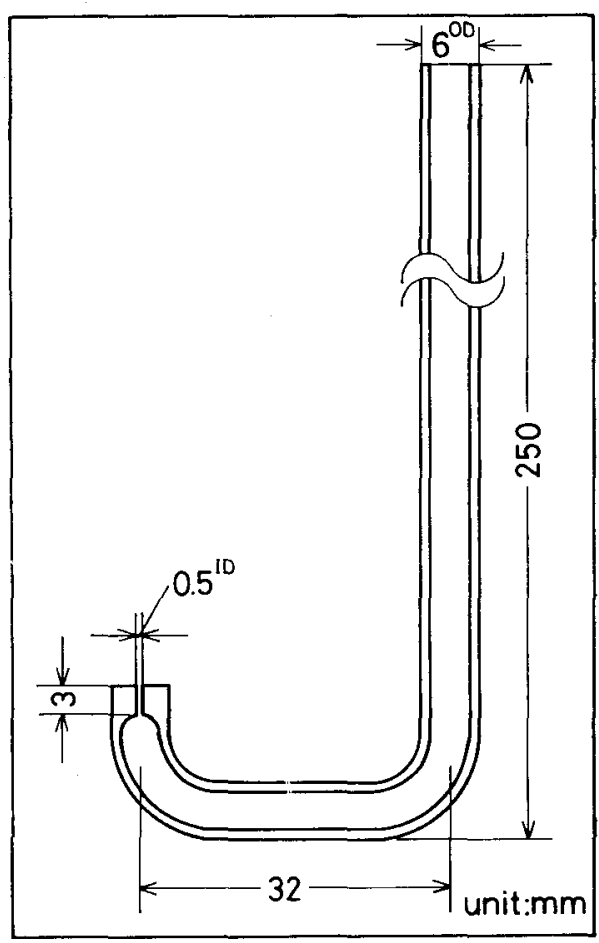

Fig. 2 Glass nozzle

and $C_{\mathrm{O}_{2}}$ were continuously made with a Hitachi-Horiba $\mathrm{pH}$ meter of type $42-\mathrm{A}$ and with a Union Giken oxygen meter of type OX-101, respectively. Styrofoam floats were placed on the surface of solution in order to prevent as far as possible the dissolution of oxygen from the surface.

Analytical reagent grade $\mathrm{FeSO}_{4} \cdot 7 \mathrm{H}_{2} \mathrm{O}$ was 
dissolved in an aqueous $\mathrm{H}_{2} \mathrm{SO}_{4}$ solution $(\mathrm{pH} \fallingdotseq$ 1). Electrolytic iron powder was added, and the solution was preserved for a few weeks to reduce the contaminated $\mathrm{Fe}^{3+}$ ion. It was filtered, and the aliquot was used for the expriment. On the other hand, a prescribed amount of analytical reagent grade $\mathrm{NaHCO}_{3}$ was dissolved in the deionized water of $990 \mathrm{~cm}^{3}$, and it was transferred into the reaction vessel. After placing the styrofoam floats on the surface of solution, the mixed gas of $\mathrm{N}_{2}$ and $\mathrm{CO}_{2}$ of a predetermined composition was bubbled through the glass nozzle at the experimental temperature for about $10 \mathrm{~h}$ in order to remove the dissolved oxygen. Then an aliquot of the above $\mathrm{FeSO}_{4}$ solution was added, and the test solution of $0.01 \mathrm{M} \mathrm{FeSO}_{4}$ and $0.1 \mathrm{M} \mathrm{NaHCO}_{3}$ was made up. The concentration of $\mathrm{Fe}^{2+}$ ion in the test solution was measured at the start of each experimental run.

After examining that $\mathrm{pH}$ of the solution was maintained at the predetermined level, $\mathrm{O}_{2}$ gas was added to the above gas stream, and the oxidation was started. The partial pressure of $\mathrm{O}_{2}$ in the mixed gas stream was maintained at $0.2 \mathrm{~atm}$. The flow rate of the mixed gas was represented by the Reynolds number at the glass nozzle. It is possible to correlate this Reynolds number with the size distribution of rising gas bubbles in the solution by applying the experimental results obtained by Leibson ${ }^{5)}$ and Tadaki. ${ }^{6}$ At the appropriate time intervals after the start of oxidation, aliquots of the solution were pipetted and placed in $1: 4$ $\mathrm{H}_{2} \mathrm{SO}_{4}$ solution to quench the reaction. Colloidal hydroxide was dissolved by heating the solution, and the concentration of $\mathrm{Fe}^{2+}$ ion was determined by titrating it against a standard $0.01 \mathrm{M} \mathrm{KMnO}_{4}$ solution.

In the first place, the effect of $\mathrm{pH}$ was studied. By changing the partial pressure of $\mathrm{CO}_{2}$ in the mixed gas stream, $\mathrm{pH}$ was adjusted at a predetermined level between 6.0 and 7.7. The oxidation was conducted at $25^{\circ} \mathrm{C}$. The flow rate of the mixed gas stream was maintained at the Reynolds number of 4000 at the glass nozzle. The results are shown in Fig. 3. As seen in this figure, the overall rate of oxidation increased with $\mathrm{pH}$. It is also seen that $C_{\mathrm{O}_{2}}$ rose from the start of oxidation and imme-

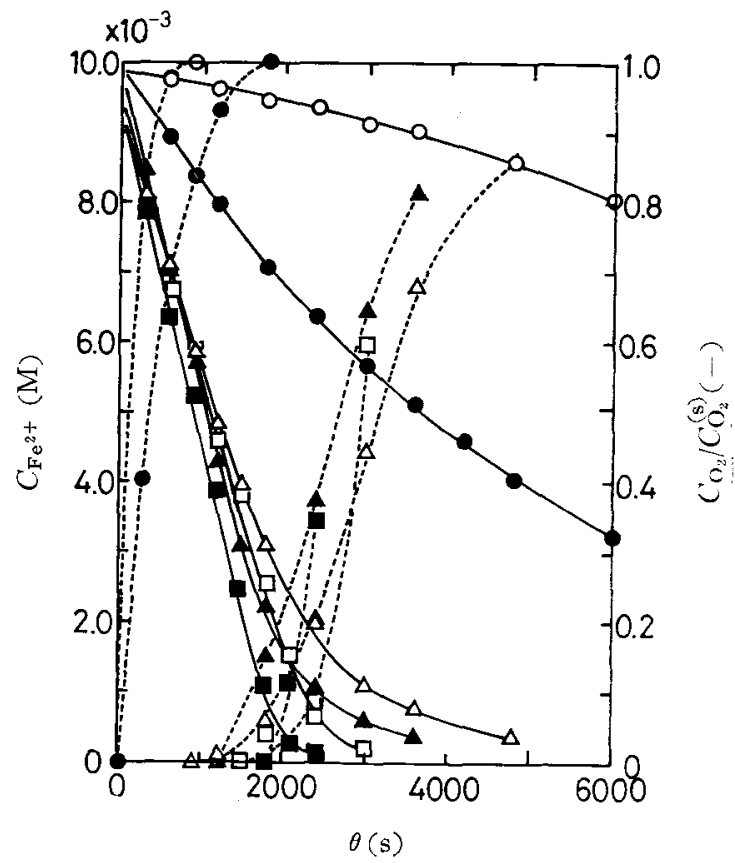

Fig. 3 Effect of $\mathrm{pH}$ on the rate of oxidation $\left(25^{\circ} \mathrm{C}, \mathrm{Re}=4000\right)$
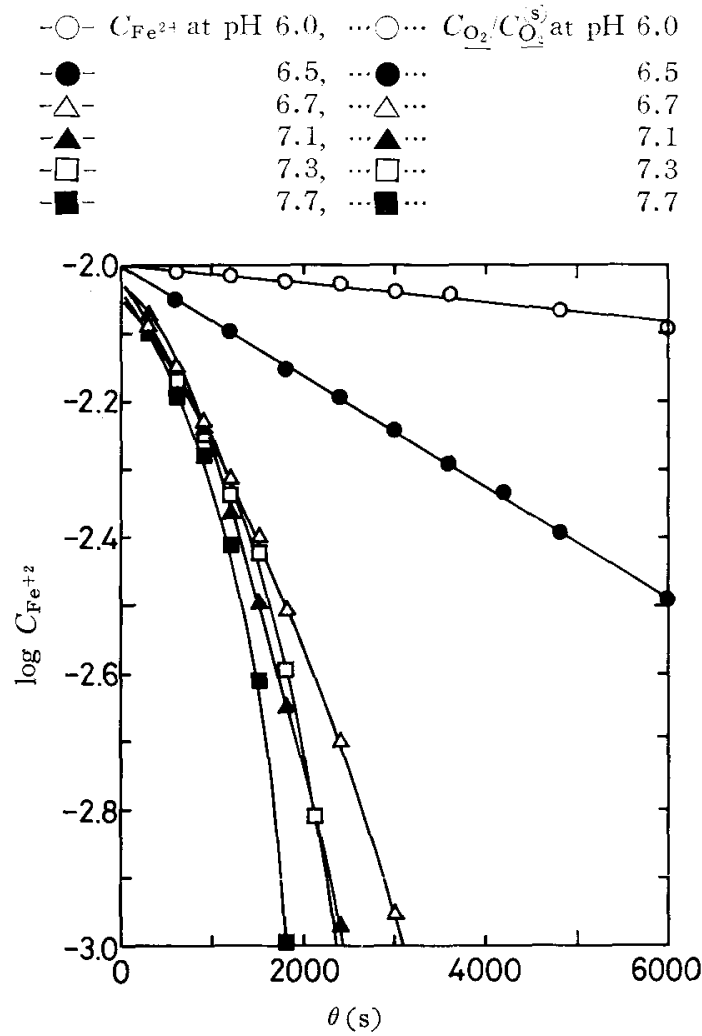

Fig. 4 Plot of $\log C_{\mathrm{Fe}^{2+}+\text { rs. } \theta}$

$-\bigcirc-\mathrm{pH}=6.0,-\bigcirc-\mathrm{pH}=6.5,-\triangle-\mathrm{pH}=6.7$
$-\mathbf{\Delta}-\mathrm{pH}=7.1,-\square-\mathrm{pH}=7.3,-\square-\mathrm{pH}=7.7$ 
diately reached the saturation at $\mathrm{pH}$ of 6.0 and 6.5. At pH higher than 6.7, on the other hand, $C_{\mathrm{O}_{3}}$ was found to be zero until $C_{\mathrm{Fe}^{2+}}$ was lowered to about $0.004 \mathrm{M}$ due to the progress of oxidation, and thereafter it increased. In order to seek for the experimental rate equation, $\log C_{\mathrm{Fe}^{2+}}$ was plotted against $\theta$ in Fig. 4. As seen from the plots at $\mathrm{pH} 6.0$ and 6.5 , they were linear. This means that the firse order rate equation holds at these $\mathrm{pH}$. On the contrary, it was observed in Fig. 3 that $\mathrm{C}_{\mathrm{Fe}^{2}}$ linearly decreased in the oxidation at $\mathrm{pH}$ above 6.7 during the period in which $\mathrm{C}_{\mathrm{O}_{2}}$ was zero. This may suggest that the zero order rate equation holds during this period of oxidation.

The effect of temperature was examined. At the temperature of $0^{\circ}, 10^{\circ}, 15^{\circ}, 25^{\circ}$ and $35^{\circ} \mathrm{C}$, the mixed gas was bubbled at the Reynolds number of 1000 , and $\mathrm{pH}$ was maintained at 6.8. The experimental results are summarized in Fig. 5. It is seen in this figure that the

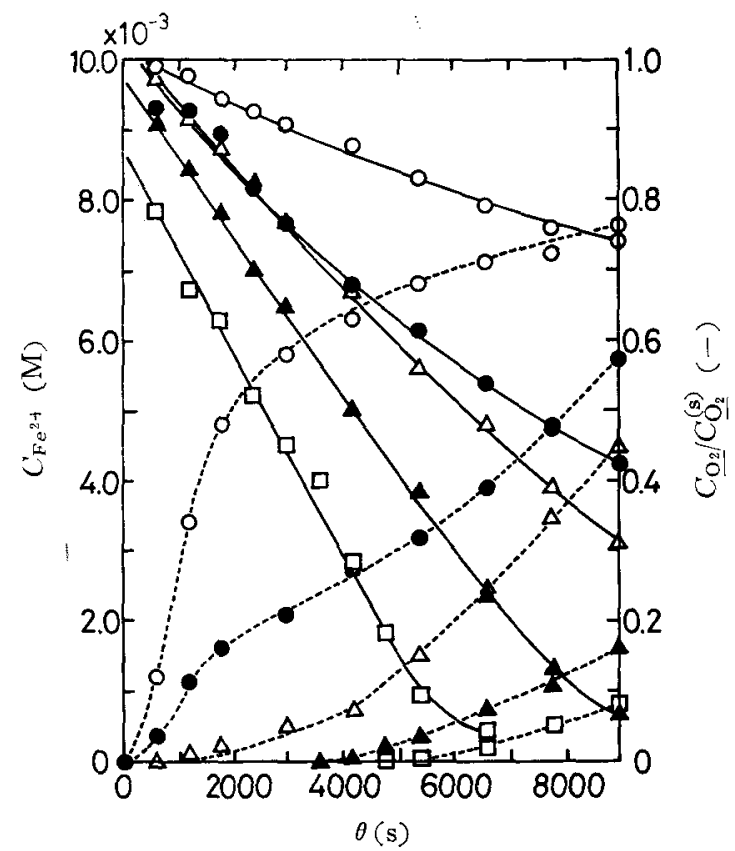

Fig. 5 Effect of temperature on the rate of oxidation $(\mathrm{pH} 6.3, \mathrm{Re}=1000)$

\begin{tabular}{|c|c|c|}
\hline & $0^{\circ} \mathrm{C}, \cdots \bigcirc$ & $+0^{\circ} \mathrm{C}$ \\
\hline & $10^{\circ} \mathrm{C}, \cdots$ & $10^{\circ} \mathrm{C}$ \\
\hline$-\triangle$ & $15^{\circ} \mathrm{C}, \cdots \triangle^{\cdots}$ & $15^{\circ} \mathrm{C}$ \\
\hline-1 . & $25^{\circ} \mathrm{C}, \cdots<\cdots$ & $25^{\circ} \mathrm{C}$ \\
\hline & $35^{\circ} \mathrm{C}, \cdots \square \cdots$ & 3 \\
\hline
\end{tabular}

rate of oxidation increased with the temperature. It is also seen at lower temperature that $C_{\mathrm{O}_{z}}$ rose immediately after the start of oxidation. At higher temperature of $25^{\circ}$ and $35^{\circ} \mathrm{C}$, on the contrary, the rise of $C_{\mathrm{O}_{2}}$ was retarded, and $C_{\mathrm{Fe}^{2}}{ }^{2+}$ decreased linearly with the elapsed time during the period of zero $C_{\mathrm{O}_{2}}$, which implied a zero order reaction. From the examination of the plot of $\log C_{\mathrm{Fe}^{2+}}$ versus $\theta$, no linear relationship was found.

In order to pursue the effect of the flow rate of the mixed gas stream, the oxidation was carried out at $25^{\circ} \mathrm{C}$ at various Reynolds numbers between 500 and 6000 . The $\mathrm{pH}$ value was maintained at 6.8 . The results are summarized in Fig. 6. As seen in this figure, the rate of oxidation increased with the Reynolds number. It is also seen that $C_{\mathrm{O}_{2}}$ remained extremely low during the course of oxidation at the lower Reynolds number. It rose sooner after the start of oxidation at higher Reynolds

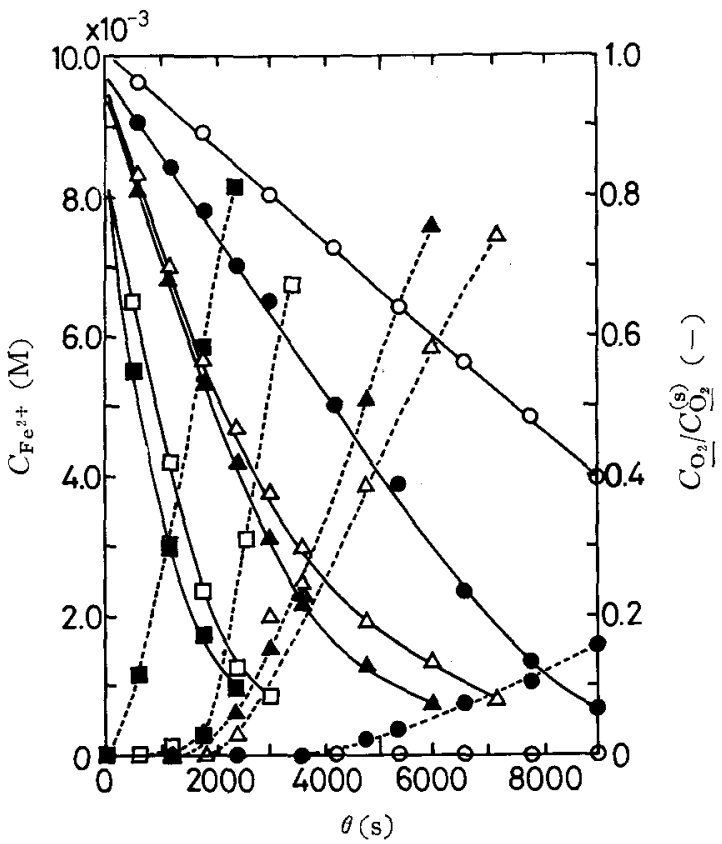

Fig. 6 Effect of Reynolds number on the rate of reaction $\left(25^{\circ} \mathrm{C}, \mathrm{pH} 6.3\right.$ )

$-O-C_{\mathrm{Fe}^{2+}}$ at $\mathrm{Re}=500, \cdots \bigcirc \cdots C_{\mathrm{O}_{2}} / C_{\mathrm{O}_{2}}^{(\mathrm{s})}$ at $\mathrm{Re}=500$

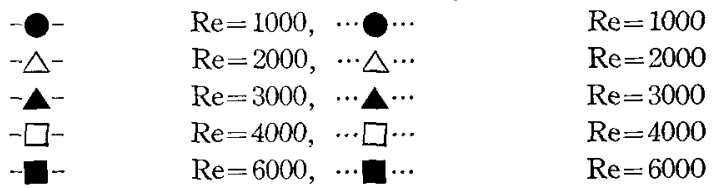


number. The concentration of $\mathrm{Fe}^{2+}$ ion linearly decreased at lower Reynolds number of 500 and 1000 during the period in which $C_{\mathrm{O}_{2}}$ was very low. From the plot of $\log C_{\mathrm{Fe}^{2+}}$ versus $\theta$, however, no linear relationship was found even when the Reynolds number is higher.

\section{Discussion}

As mentioned earlier, the oxidation of a neutral $\mathrm{FeSO}_{4}$ solution by $\mathrm{O}_{2}$ gas is composed of the sequential steps of the dissolution of $\mathrm{O}_{2}$ gas at the surface of rising gas bubbles and the oxidation of $\mathrm{Fe}^{2+}$ ion by $\mathrm{O}_{2}$ in the solution, which were shown in eq. (1) and (3), respectively. Furhermore, the former step of oxygen dissolution occurring at the gas-liquid interface may be composed of

1. the mass transfer of $\mathrm{O}_{2}$ gas in the gas boundary film within the bubbles,

2. the dissolution of $\mathrm{O}_{2}$ gas at the bubble surface, and

3. the mass transfer of $\mathrm{O}_{2}$ in the liquid boundary film adjacent to the bubbles.

It may be a reasonable presumption that the step 3 determines the overall rate of oxygen dissolution.

Regarding the rate of reaction between $\mathrm{Fe}^{2+}$ ion and $\mathrm{O}_{2}$, eq. (4) proposed by Stumm et al. ${ }^{2)}$ may be rewritten as

$$
-\frac{\mathrm{d} C_{\mathrm{Fe}^{2+}}}{\mathrm{d} \theta}=k_{1} C_{\mathrm{Fe}^{2}}+C_{\mathrm{O}_{2}} C_{\mathrm{OH}^{-}}^{2-}
$$

On the other hand, Holluta et al. ${ }^{7)}$ proposed that the oxidation of $\mathrm{Fe}^{2+}$ ion is composed of the sequential reactions of

$$
\mathrm{Fe}^{2+}+\frac{1}{4} \mathrm{O}_{2}+\mathrm{H}^{+} \longrightarrow \mathrm{Fe}^{3+}+\frac{1}{2} \mathrm{H}_{2} \mathrm{O}
$$

and

$$
\mathrm{Fe}^{3+}+3 \mathrm{H}_{2} \mathrm{O} \longrightarrow \mathrm{Fe}(\mathrm{OH})_{3}+3 \mathrm{H}^{+}
$$

and the overall rate is determined by the former reaction (6). They proposed the rate equation of

$$
-\frac{\mathrm{d} C_{\mathrm{Fe}^{2+}}}{\mathrm{d} \hat{\theta}}=k_{2} C_{\mathrm{Fe}^{2+}} C_{\underline{\mathrm{O}_{3}}} C_{\mathrm{OH}^{-}}
$$

These rate equations (5) and (8) may be expressed in a generalized form of

$$
-\frac{\mathrm{d} C_{\mathrm{Fe}^{2+}}}{\mathrm{d} \theta}=k_{\mathrm{r}} C_{\mathrm{Fe}^{2+}} C_{\mathrm{O}_{2}} C_{\mathrm{OH}^{-}}^{2}
$$

In this equation, the parameter $\alpha$ is between 1 and 2.

The time variation of $\mathrm{C}_{\mathrm{O}_{2}}$ is written as

$$
\frac{\mathrm{d} C_{\mathrm{O}_{2}}}{\mathrm{~d} \theta}=\frac{S}{V} k_{\mathrm{L}}\left(C_{\underline{\mathrm{O}_{2}}}^{(\mathrm{s})}-C_{\mathrm{O}_{2}}\right)+\frac{1}{4} \frac{\mathrm{d} C_{\mathrm{Fe}^{2+}}}{\mathrm{d} \theta}
$$

The superscript ( $\mathrm{s}$ ) denotes the saturated value. The first term on the right-hand side of this equation represents the dissolving rate of $\mathrm{O}_{2}$ gas which is determined by the transferring rate of $\mathrm{O}_{2}$ in the liquid boundary film of gas bubbles, and the second term represents the consuming rate of $\underline{\mathrm{O}_{2}}$ due to the reaction with $\mathrm{Fe}^{2+}$ ion.

When the overall rate of the oxidation is controlled solely by the dissolving rate of $\mathrm{O}_{2}$ gas, $C_{\mathrm{O}_{2}}$ is presumed to be $C_{\underline{\mathrm{O}_{2}}}^{(\mathrm{e})}$ which is the equilibrium concentration of $\mathrm{O}_{2}$ of eq. (3). It is unvaried at a constant temperature.

Then

$$
\frac{\mathrm{d} C_{\mathrm{O}_{2}}}{\mathrm{~d} \theta}=0
$$

Furthermore, presuming that $C_{\underline{\mathrm{O}}_{3}}^{(\mathrm{e})}$ is far lower than $C_{\mathrm{O}_{2}}^{(\mathrm{s})}$, eq. (10) is rewritten as

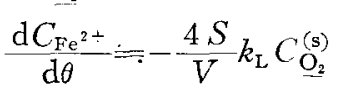

which is the zero order rate equation.

when the overall rate is solely controlled by the rate of reaction between $\mathrm{Fe}^{2+}$ ion and $\underline{\mathrm{O}}_{2}$, on the other hand, $\mathrm{C}_{\mathrm{O}_{2}}$ is presumed to be equal to $\mathrm{C}_{\mathrm{O}_{2}}^{(\mathrm{s})}$.

Then eq. (9) is rewritten as

$$
-\frac{\mathrm{d} C_{\mathrm{Fe}^{2+}}}{\mathrm{d} \theta}=k_{\mathrm{r}} C_{\mathrm{Fe}^{2+}} C_{\mathrm{O}_{2}}^{(\mathrm{s})} C_{\mathrm{OH}^{-}}^{2}
$$

It is the first order rate equation with regard to $\mathrm{C}_{\mathrm{Fe}}{ }^{2+}$ when $\mathrm{pH}$ is maintained constant.

When the overall rate of the oxidation is affected by both rates of the dissolution of $\mathrm{O}_{2}$ gas and the reaction $\mathrm{Fe}^{2+}$ ion and $\underline{\mathrm{O}_{2}}, \mathrm{C}_{\mathrm{O}_{2}}$ does not remain constant but increases along with the progress of the oxidatian. By eliminating $C_{\mathrm{O}_{2}}$ from the simultaneous rate equations (9) and (10), we have

$$
\begin{aligned}
& k_{\mathrm{r}}{ }^{\prime}=k_{\mathrm{r}} C_{\mathrm{OH}^{-}}^{\alpha} \\
& =\frac{\frac{1}{C_{\mathrm{Fe}^{2+}}}\left(\frac{\mathrm{d} C_{\mathrm{Fe}^{2+}}}{\mathrm{d} \theta}\right)^{2}-\frac{S}{V} k_{\mathrm{L}} \frac{\mathrm{d} C_{\mathrm{Fe}^{2+}}}{\mathrm{d} \theta}-\frac{\mathrm{d}^{2} C_{\mathrm{Fe}^{2+}}}{\mathrm{d} \theta^{2}}}{C_{\mathrm{Fe}^{2+}}\left(\frac{S}{V} k_{\mathrm{L}} C_{\mathrm{O}_{2}}^{(\mathrm{s})}+\frac{1}{4} \frac{\mathrm{d} C_{\mathrm{Fe}^{2+}}}{\mathrm{d} \theta}\right)}
\end{aligned}
$$


From this equation, the rate constant $k_{\mathrm{r}}^{\prime}(=$ $\left.k_{\mathrm{r}} \mathrm{COH}^{\alpha}\right)$ was calculated. The mixed gas stream of $\mathrm{O}_{2}, \mathrm{~N}_{2}$ and $\mathrm{CO}_{2}$ wa blown through the same glass nozzle shown in Fig. 2 into the reaction vessel filled with deionized water, and the dissolving rate of $\mathrm{O}_{2}$ gas was measured. The obtained $(S / V) k_{\mathrm{L}}$ values were used in the calculation. The value of $C_{\underline{\mathrm{O}_{2}}}^{(\mathrm{s})}$ was referred to a literature ${ }^{s)}$ presuming that $C_{\mathrm{O}_{2}}^{(\mathrm{s})}$ in water and in aqueous $\mathrm{FeSO}_{4}$ solution are virtually equal. Furthermore, $\left(\mathrm{d} C_{\mathrm{Fe}^{2+}}+\mathrm{d} \theta\right)$ and $\left(\mathrm{d}^{2} C_{\mathrm{Fe}^{2}}{ }^{2} / \mathrm{d} \theta^{2}\right)$ values were obtained graphically from the plot of $C_{\mathrm{Fe} 2+}$ versus $\theta$.

The calculation was carried out with the experimental results of Fig. 3, and the logarithm of the obtained $k_{\mathrm{r}}{ }^{\prime}$ value was plotted against $\mathrm{pH}$. It is shown in Fig. 7. It is seen

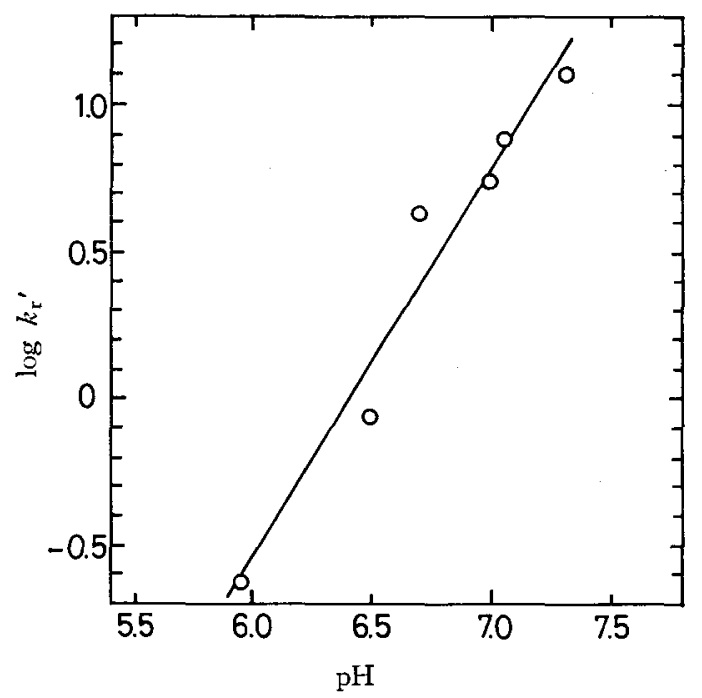

Fig. 7 Plot of $\log k_{\mathbf{r}}{ }^{\prime}$ vs. $\mathrm{pH}\left(25^{\circ} \mathrm{C}\right.$, $\mathrm{Re}=4000$ )

that a linear relationship holds between them. From the slope of this straight line, the parameter $\alpha$ was calculated to be 1.33 by the least squares method. It may be written that

$$
k_{\mathrm{r}}=k_{\mathrm{r}}{ }^{\prime} / C_{\mathrm{OH}^{-}}^{1.33}
$$

Under the experimental conditions that the temperature is $0^{\circ}, 10^{\circ}$ and $15^{\circ} \mathrm{C}$ and the Reynolds number is maintained at 1000 shown in Fig. 5 and that the temperature is maintained at $25^{\circ} \mathrm{C}$ and the Reynolds number is 2000 , 3000,4000 and 6000 shown in Fig. 6, respectively, it is thought that the oxidation is

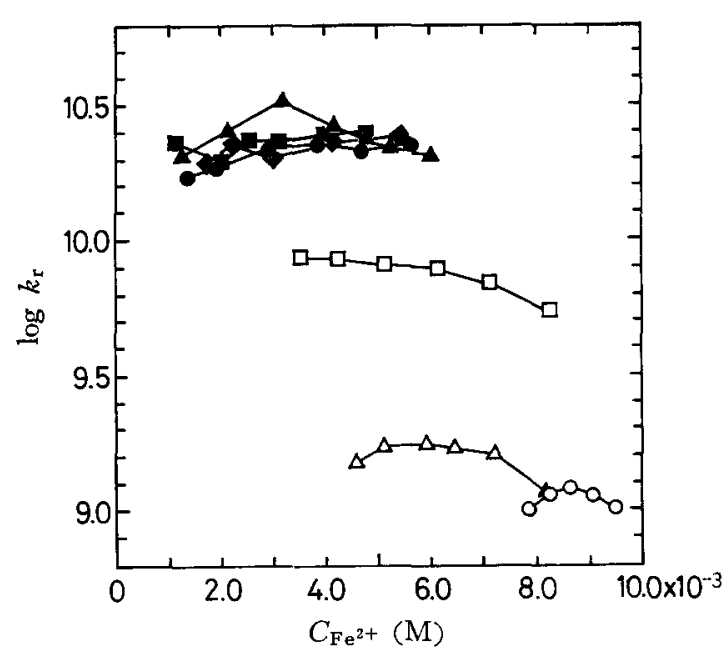

Fig. 8 Plot of $\log k_{\mathrm{r}} v s . \mathrm{C}_{\mathrm{Fe}^{2+}}$

- $\mathrm{O}$ - at $0^{\circ} \mathrm{C}$ and $\mathrm{Re}=1000,-\mathrm{O}$ - at $25^{\circ} \mathrm{C}$ and $\mathrm{Re}=2000$

$-\triangle-\quad 10^{\circ} \mathrm{C} \quad \operatorname{Re}=1000,-\Delta-\quad 25^{\circ} \mathrm{C} \quad \operatorname{Re}=3000$

$-\square-\quad 15^{\circ} \mathrm{C} \quad \operatorname{Re}=1000,-25^{\circ} \mathrm{C} \quad \mathrm{Re}=4000$

$$
-25^{\circ} \mathrm{C} \quad \mathrm{Re}=6000
$$

of mixed control of the mass transfer of $\mathrm{O}_{3}$ and the chemical reaction. The rate constant $k_{\mathrm{r}}$ was calculated from these experimental results, and $\log k_{\mathrm{r}}$ was plotted against $C_{\mathrm{Fe}}{ }^{2+}$ in Fig. 8. In this figure, no systematic time variation of $k_{\mathrm{r}}$ is observed along the progress of the oxidation. The temperature variation of the mean value of $k_{\mathrm{r}}$ is evident, while it is virtually unvaried at different Reynolds numbers. From this behavior of $k_{\mathrm{r}}$ value, the calculated $k_{\mathrm{r}}$ is thought to satisfy the condition that the reaction

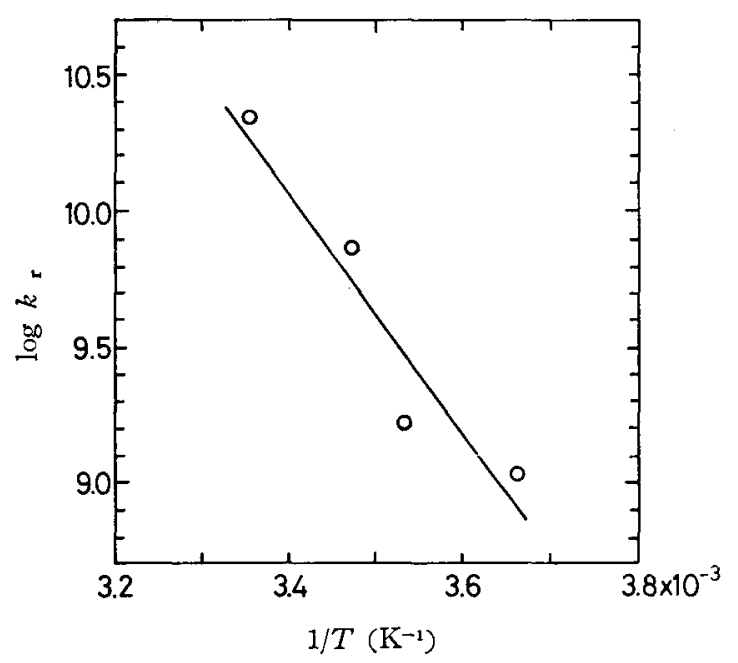

Fig. 9 Arrhenius plot of $k_{\mathrm{r}}$ 
(3) is of homogeneous character. From the Arrhenius plot of the mean $k_{\mathrm{r}}$ values shown in Fig. 9, the activation energy of $21 \mathrm{kcal} / \mathrm{mol}$ was obtained. This value is in good agreement with $23 \mathrm{kcal} / \mathrm{mol}$ reported by Stumm et al. ${ }^{2}$ )

The temperature variation of the liquid-film mass transfer coefficient of $\mathrm{O}_{2}$ in the form of $S k_{\mathrm{L}}$ was also investigated: $S k_{\mathrm{L}}$ values were calculated from the slope of the straight lines at $15^{\circ}, 25^{\circ}$ and $35^{\circ} \mathrm{C}$ shown in Fig. 5, and $\ln \left(S k_{\mathrm{L}}\right)$ was plotted against $\mathrm{l} / T$. The obtained apparent activation energy was $7 \mathrm{kcal} / \mathrm{mol}$. This value is thought to be appropriate as a measure of temperature variation of the mass transfer coefficient in liquid phase.

Furthermore, the variation of $S k_{\mathrm{L}}$ due to the flow rate of the mixed gas flow was investigated. It was presumed from Fig. 6 that the mass transfer of $\mathrm{O}_{2}$ in the liquid boundary film is the rate determining step below the Reynolds number of 1000 and that the oxidation is of mixed control of mass transfer and chemical reaction above the Reynolds number of 2000 . The $S k_{\mathrm{L}}$ value was calculated from the linear portion of $C_{\mathrm{Fe}^{2+}}{ }^{2+}$ versus $\theta$ curves obtained in the former stage of the oxidation shown in Fig. 6 where $C_{\mathrm{O}_{2}}$ is maintained at zero. They were plotted against the Reynolds number in Fig. 10. As seen in this diagram, $S k_{\mathrm{L}}$ value

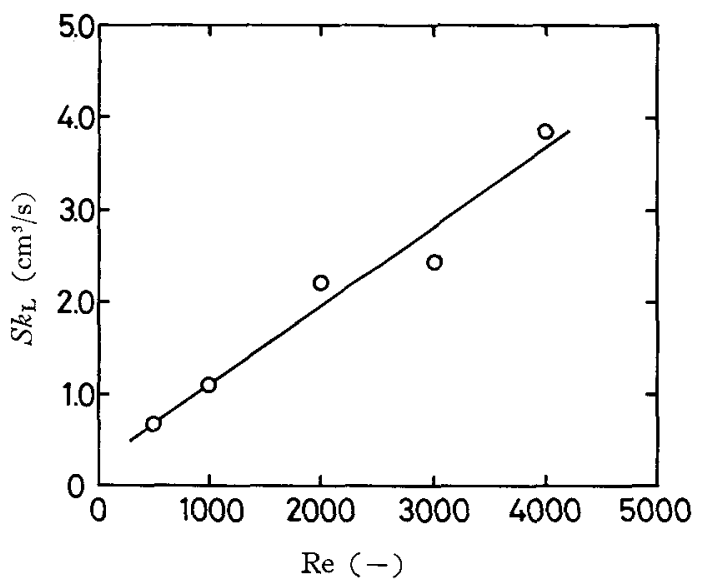

Fig. 10 Plot of $S k_{\mathrm{L}} \approx s . \operatorname{Re}\left(25^{\circ} \mathrm{C}, \mathrm{pH} 6.8\right)$

linearly increases with the Reynolds number. The increase of $S k_{\mathrm{L}}$ value may be mainly attributed to the increased surface area of the rising gas bubbles at higher Reynolds number.

\section{Summary}

The oxidation of neutral $\mathrm{FeSO}_{4}$ solution by $\mathrm{O}_{2}$ gas was studied in the present work. The mixed gas of nitrogen, oxygen and $\mathrm{CO}_{2}$ was blown from an upward vertical glass nozzle of $0.5 \mathrm{~mm}$ in inner diameter into the solution. The $\mathrm{pH}$ of the solution was maintained at the predetermined level between 6.0 and 7.7 by changing the partial pressure of $\mathrm{CO}_{2}$ in the mixed gas stream. The concentrations of $\mathrm{Fe}^{2+}$ ion and the dissolved oxygen were measured during the progress of the oxidation.

The overall rate of oxidation increased with the rise of $\mathrm{pH}$. At $\mathrm{pH}$ above 6.7 , the concentration of dissolved oxygen was maintained at zero in the former part of the oxidation, and the overall rate was controlled by the transferring rate of dissolved oxygen in the liquid boundary film adjacent to the gas bubbles. The rate of reaction between $\mathrm{Fe}^{2+}$ ion and dissolved oxygen was revealed to be proportional to the $4 / 3$ th power of $C_{\mathrm{OH}^{-}}$.

The temperature variation of the overall rate of oxidation was pursued with the aqueous solution of $\mathrm{pH} 6.8$ and at the Reynolds number of 1000 . At higher temperature above $25^{\circ} \mathrm{C}$, the concentration of dissolved oxygen was virtually zero during the progress of oxidation, and the reaction was of mass transfer control of dissolved oxygen. At lower temperature, on the other hand, the overall rate was affected by both rates of mass transfer and chemical reaction. The rate constant of the reaction between $\mathrm{Fe}^{2+}$ ion and dissolved oxygen was calculated, and the activation energy of $21 \mathrm{kcal}$ /mol was obtained.

The overall rate of the oxidation increased with the Reynolds number of the mixed gas stream under the experimental conditions of $25^{\circ} \mathrm{C}$ and $\mathrm{pH} 6.8$. In the region below the Reynolds number of 1000 , the concentration of dissolved oxygen remained extremely low, and the oxidation was of mass transfer control. The transferring rate of dissolved oxygen in the liquid boundary film increased with the Reynolds number mainly due to the increase of the surface area of rising gas bubbles. In the region of the Reynolds number above 2000 , the oxidation was of mixed control of mass transfer and chemical reaction. 


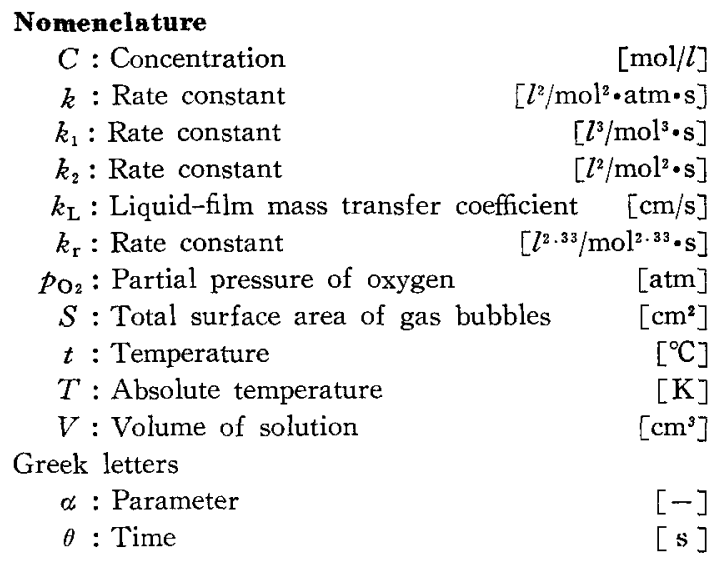

\section{References :}

1) A. Tsuda, B. Higuchi and Y. Kondo, This Journal 46, 252 (1978).

2) W. Stumm and G. F. Lee, Ind. Eng. Chem. 53, 143 (1961).

3) J.E. Schenk and W.J. Weber, Jr., J. Amer. Water Works Assoc. 60, 199 (1968).

4) H. Tamura, K. Goto and M. Nagayama, Corrosion Sci. 16, 197 (1976).

5) I. Leibson, E.G. Holcomb, A.G. Cacoso and J.J. Jacmic, AIChE J. 2, 296 (1956).

6) T. Tadaki and S. Maeda, Kagaku Kogaku 27, 147 (1963).

7) J. Holluta and W. Kölle, Das Gas-und Wasserfach 105, 471 (1964).

8) JIS K 0102, p. 74 (1974), Japan Standards Association, Tokyo.

シシや語単行本入手の要謗は出来る限り早く注文することです. 本の洒格が安いのは大きな魅力です, 各項は著者名, 書名, 頁数

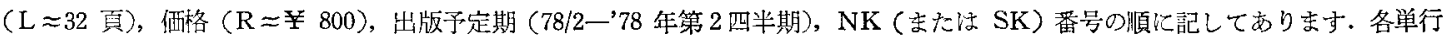
本の詳しい内容を知りたいすは NK（SK）を備えた専門店へどうぞ。

(1) Vyacheslavov et al., 電解加工, $15 \mathrm{~L}, 0.75 \mathrm{R}, 79 / 1$, NK $32-63 / 78$

(2) Mel'nikov，機晠製作见おける電解被覆ハンドブック， $30 \mathrm{~L}, 2.0 \mathrm{R}, 79 / 2$, NK $32-70 / 78$

(3) Raevskaya et al.,ルテニウム抢よびその合金の物理化 学 $20 \mathrm{~L}, 2.4 \mathrm{R}, 79 / / 2$, NK 35-124/78

(4) Gerasimov et al. (ed.) 物理化学の現在の諸問題 Vol. 11 (分子搆造), $20 \mathrm{~L}, 3.15 \mathrm{R}, 79 / 3$, NK 35-218/78

(5) Gerasimov et al. (ed.) 物理化学の現在の諸問題 Vol. 12 (反応速度), $20 \mathrm{~L}, 2.15 \mathrm{R}, 79 / 1, \mathrm{NK} 35-219 / 78$

(6) Gerasimov et al., 溶液の熱力学講義, $15 \mathrm{~L}, 0.7 \mathrm{R}, 79 / 2$, NK $35-302 / 78$

(7) Kravtsov et al., 電気化学実験ハンドブッ, $14 \mathrm{~L}$, $0.59 \mathrm{R}, 79 / 1$, NK $35-317 / 78$

(8) Rannev, クロ/ポテンシォグラフ, $11 \mathrm{~L}, 0.55 \mathrm{R}, 79 / 3$, NK $36-63 / 78$

(9) Pankov et al., 誘電体基板上のエピタキシャルケイ素 層, 5.5 L, 0.3 R, 79/3, NK 36-227/78

(10) Orekhova et al., 電気メッキにおけるボリリガンド電解 質, $10 \mathrm{~L}, 1.5 \mathrm{R}, 79 / 3$, NK 38-75/78

(11) 金属上の保護被覆, 第 13 分册, $10 \mathrm{~L}, 1.5 \mathrm{R}, 79 / 3, \mathrm{NK}$ 38-91/78

(12) Zhuravlev, 不可逆過程の熱力学（解答付問題集)，6L, $0.4 \mathrm{R}, 79 / 2$, NK $39-94 / 78$
(13) 水如理技術化和ける酸化剂 (Monograph), $20 \mathrm{~L}, 3.40 \mathrm{R}$, $79 / 3$, NK $41-159 / 78$

(4) Zheludev, 電気的結晶, $10 \mathrm{~L}, 0.65 \mathrm{R}, 79 / 1, \mathrm{NK} 43-192 / 78$

(15) Avdonin, 結晶化過程の数学的記述, $10 \mathrm{~L}, 0.95 \mathrm{R}, 79 / 2$, NK $44-33 / 78$

(16) Kirilyus, Electrocatalytic 水素化, $14 \mathrm{~L}, 2.50 \mathrm{R}, 79 / 3$, NK $44-53 / 78$

(17) Kir'yakov et al., 硫酸溶液中に护石覀鉛と鉛の腐食, $6 \mathrm{~L}, 0.90 \mathrm{R}, 79 / 1, \mathrm{NK} 44-54 / 78$

(18) Sokol'skii et al., 酸化還元反応の不均一触媒の電気化学 的 aspects, $12 \mathrm{~L} 2.10 \mathrm{R}, 79 / 1$, NK 44-58/78

(19) Aleksandrov et al., 半導体中の内部摩擦と欠陌, $11 \mathrm{~L}$, 1.70 R, 79/3, SK-1-2-33/78

(20) Ivanovskii et al., ガスおよびイオン性融体，12 L, 1.80R, $79 / 1$, SK-1-2-156/78

(21) Kiselev et al., 吸着における電子プロセスと触媒, $81 \mathrm{~L}$, 1.80 R, 79/2, SK-1-2-160/78

(22) Lazarev et al., 酸化物系および膜棈造の電導度, $12 \mathrm{~L}$, $1.80 \mathrm{R}, 79 / 3$, SK-1-2-164/78

(23) 薄膜沈打る表面力, $20 \mathrm{~L}, 2.80 \mathrm{R}, 79 / 1, \mathrm{SK}-1-2-171 / 78$

(24) モノマ一の電解合成(有機化合物の電気化学の進歩), $25 \mathrm{~L}$, $4.25 \mathrm{R}, 79 / 3$, SK-1-2-188/78

(25) Smirnov et al.タルカリ金属の溶融ハロゲン化物とその 二元系混合物の粘度, $10 \mathrm{~L}, 1.0 \mathrm{R}, 79 / 1, \mathrm{SK}-1-2-901 / 78$ 